九州大学学術情報リポジトリ

Kyushu University Institutional Repository

\title{
Policy Analysis on Cadaveric Kidney Donation and Transplantation
}

Pangesty, Azizah Intan

Interdisciplinary Graduate School of Engineering Sciences, Kyushu University

https://doi.org/10.5109/1936216

出版情報 : Evergreen. 5 (2)，pp.44-49，2018-06. 九州大学グリーンアジア国際リーダー教育センター バージョン：

権利関係 : 


\title{
Policy Analysis on Cadaveric Kidney Donation and Transplantation
}

\author{
Azizah Intan Pangesty* \\ Interdisciplinary Graduate School of Engineering Sciences, Kyushu University \\ 6-1 Kasuga-koen, Kasuga, Fukuoka, 816-8580, Japan \\ *Author to whom correspondence should be addressed, \\ E-mail: p.azizah.364@s.kyushu-u.ac.jp
}

(Received February 28, 2018; accepted June 4, 2018).

\begin{abstract}
The increase of successful rate of kidney transplantation has made this treatment as a major preference for patient with end-stage renal disease. As a result, the waiting list for kidney transplantation has been progressively increasing every year. This condition has forced many countries to make policies to increase the supply of kidney. This article discussed three major policies on cadaveric kidney donation. The first policy is opt-in system which requires people to register as a donor before their death (informed consent). The second policy is opt-out system in which every individual is automatically treated as a donor (presumed consent) unless otherwise requested. The third policy is regulated-paid donation in which the donors receive financial incentives for their kidney donation. The purpose of this study is to review these three main strategies including whether or not the policies have an impact to increase kidney donation. It was found that the reviewed policies have less effect on increasing the number of kidney sources. It seems that these policies were not effective without public willingness for renal donation. Furthermore, the transplantation facilities and procedures such as, transplant center hospitals, skilled medical personnel and transplant network also played important roles to increase kidney donation. As conclusion, to increase the supply of kidney, the implemented policy should be supported by good public attitudes and effective transplantation system.
\end{abstract}

Keywords: policy analysis, presumed consent, informed consent, financial incentive, kidney donation.

\section{Introduction}

Since the discovery of immunosuppressant ${ }^{*}$ in 1960 , organ transplantation has been widely performed and seems to be the gold treatment for an end-stage of organ failure patient. As of 2015, around 84,347 of kidney transplants had been carried out in 89 countries $^{1)}$. Also, advances in organ transplant technology that increased the graft's and the patient's survival rate have made kidney transplantation becomes a preference over dialysis $^{\dagger}$ treatment. Renal patients who received a kidney transplant live longer than those stayed on dialysis. Patients with a kidney transplant at the age of 55 have 10 years longer live expectancy than dialysis patient ${ }^{2,3)}$. Kidney transplantation is also more cost effective than dialysis ${ }^{4,5)}$. In the United States, hemodialysis treatment costs approximately $\$ 87,000$ annually6), while the average cost for post-operative care for kidney transplant

\footnotetext{
* a drug that prevents the body from rejecting foreign materials

† a therapy for patient whose kidney unable to filter blood adequately
}

is only around $\$ 29,000$ per year ${ }^{7}$.

Because of those wider benefits of kidney transplant over dialysis, the number of patients who register for kidney transplant increases sharply every year. Meanwhile, the supply of transplantable kidneys is much less than the demand. Based on the US Organ Procurement and Transplantation Network (OPTN) as of January 2018, around 95,354 patients were waiting for kidney transplant. With the shortage of kidney sources, the renal patient could wait 5-10 years to get kidney transplant. This condition has forced many countries to seek new strategies in order to expand kidney donor pool. Advances in biomedical technology offer an attractive strategy to create bio-artificial kidney by combining human cells and compatible materials ${ }^{8-10)}$. Unfortunately, this technology is not expected to be available in the upcoming decade ${ }^{11}$. A policy based-strategy is therefore the most possible approach to increase the rate of kidney donation.

In many countries, such as Japan, U.S and U.K the kidney donation and transplant from deceased (cadaver) donor is carried out under an informed consent law 
which provides an explicit consent for organ removal before death. In contrast, most of the European countries practice presumed consent principle which treat all the deceased as potential kidney donors unless the objection "not to donate" is mandated prior death. Currently, although it is not permitted in most countries, financial incentive for cadaver donor has also been either examined or implemented in some countries ${ }^{12)}$.

Transition of organ donation law into presumed consent is often associated as a solution to boost kidney donation rate ${ }^{13-15}$. The debate in defense of financial compensation for organ donor has also been developing in some countries such as Canada ${ }^{12)}$ and Singapore ${ }^{16)}$. Although many interesting views, challenges, and solutions were discussed, the studies were mainly focused only to individual policy and a comparison study among multiple policies was limited. Therefore, it is necessary to review these three policies in more major situation, not limited to the individual country. This study was aimed to 1) evaluate whether or not that these three mentioned policies have an impact to increase kidney donation, and 2) identify and clarify the actual key factors that increase the kidney donation number from cadaveric donor.

\section{Limitation}

This study was limited to the discussion of kidney transplant and donation from deceased (cadaver) donor.

\section{Policy Descriptions}

\subsection{Informed Consent}

In informed consent countries, organ transplant should be performed based on the altruistic principle, thus organ donation is treated as an act of gift and that any compensation due the action is not allowed. By law, the informed consent is an advance approval from individual to donate organ after death. It usually provides consent to medical authority of which organs that can be taken according to the deceased's will. Majority of countries follow this informed consent regulation which include USA, Australia, Japan, Denmark, England, Germany, The Netherlands, Canada, and Switzerland ${ }^{17)}$.

The individual registers as an organ donor through a designated body as simple as registering either by mail, email, or phone call. In some states of USA, the registration can be signed up online and they will send the donor car once the registration finished. Most states let the registrant to choose what organs and tissues they want to donate and any revisions or even withdrawal can be updated at any time ${ }^{18)}$.

In informed consent, the individual is regarded as a non-donor by defaults. They need to take action if they want to be a donor. Unfortunately, the individual who wanted to be a donor often fails to have informed consent before death. Thus, without a real action of the individual to get a donor card or to join the organ donor registry, the donation rate in the informed consent countries is hard to increase.

By law, when the deceased carrying a donor card or registration on the organ procurement center, the surgeon has appropriate consent for a removal of the organ. However, in real practice, before the organ removal is performed, the medical authority is likely to ask for family's consent though the donor carries a donor card or has made a registration for organ donation. Therefore, the family's decision renders a de facto authority of the transplant surgeon ${ }^{19)}$. The surgeon is unlikely to recover the organ without a consent from the family.

\subsection{Presumed Consent}

In informed consent countries, the system is an "opt-in" system, where individual voluntarily becomes organ donor. In contrast, in presumed consent countries, the system is known as an "opt-out" system which assumes that every deceased is willing to become organ donor. This means that the medical staff has an authority to remove organs for donation unless the patient declares the objection clearly prior death.

Presumed consent system has been adopted in majority of European countries including Spain, Norway, Austria, Belgium, France, Italy, Poland and Portugal ${ }^{20)}$.

Table 1. Comparative Evaluation of Organ Donation and Transplantation System.

\begin{tabular}{lll}
\hline System & Advantages & Drawbacks \\
\hline Informed consent & $\bullet$ No moral and ethical problems & $\begin{array}{l}\text { - Slow increase of donation rate } \\
\text { - False negative ( the kidney donation cannot } \\
\text { be proceed if no informed consent made } \\
\text { though the individual want to donate) }\end{array}$ \\
\hline Presumed consent & $\bullet \begin{array}{l}\text { Significant increase of kidney } \\
\text { donation }\end{array}$ & $\begin{array}{l}\text { - Moral and ethical questions } \\
\text { take organ against donor's will) }\end{array}$ \\
\hline $\begin{array}{l}\text { Financial } \\
\text { incentives }\end{array}$ & $\begin{array}{l}\text { Reduce financial burden of the } \\
\text { donor and the family }\end{array}$ & $\begin{array}{l}\text { - Moral and ethical questions } \\
\text { Against some religious views }\end{array}$ \\
& $\begin{array}{l}\text { A potential to increase kidney } \\
\text { donation }\end{array}$ & \\
\hline
\end{tabular}




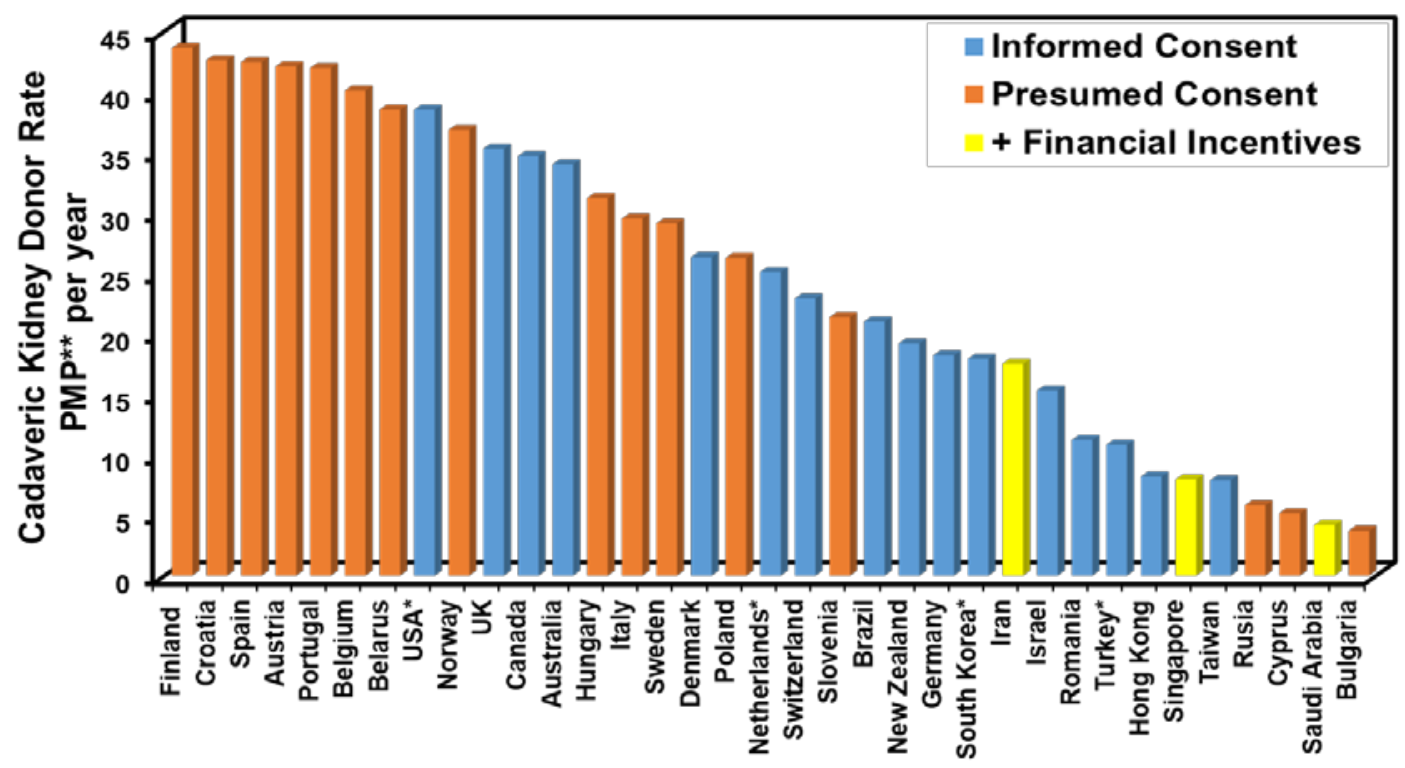

Fig 1. Kidney Donation Rate from Deceased Donor in 2016. Source: The International Registry of Organ Donation and Transplantation ${ }^{28}$. $* 2015$, ** per million population.

In Asia, presumed consent was first introduced in Singapore in $1987^{21)}$. In practice, there are 2 types of presumed consent: hard or soft, which relates to how far the family's consideration is placed ${ }^{15}$. Transplant team in countries with hard presumed consent, such as Austria and Singapore, is likely to remove organs from a deceased donor without asking the family's view. Spain has been practicing a soft presumed consent in which the medical staff is urged to consult with the donor's family prior the organ removal ${ }^{22}$.

Many transplant professionals suggested that presumed consent system is the best to increase donations rate because by default every individual (including of those who have no preference) is treated as a potential donor. In fact, an individual who does not request for "not donating" does not mean he/she agrees to be a donor. Thus a false positive where the transplant authority takes organ against donor's will is likely occurred $^{17}$. In this case, due to those moral and ethical problems, the informed consent is seen as a better system than presumed consent.

\subsection{Financial Incentives}

Most countries practice the altruistic system for organ transplantation because this policy is recommended by the World Health Organization (WHO). However, some countries are trying to seek an alternate attempt which may seem controversial. The most controversial regulation is paid organ donation which allows to give financial incentives to the donor. This concept believes that the gratefulness over the altruistic act alone is not enough to endure the harm and loss because of organ donation. Financial disadvantage, such as uncovered medical expense and lost wages during donation process, tends to discourage people for being a donor. Therefore, financial incentives offer a protection for donor and the family's and help to reduce short- or long-term financial burden as a consequence of organ donation. Some transplant experts also believed that a regulated financial incentives has a potential to increase organ donation while eliminating illegal practice of organ markets ${ }^{12)}$. Despite many potentials of regulated system of incentives, the protests against it remains continue.

The opponents claimed that financial compensation for donor is wrong in principle and unethical. Yet, numerous transplant scholars have concluded financial incentives should not be considered against ethical issues 16,23).

The form and the amount of financial incentives are regulated by the policy authority. Such incentives can be in the form of direct payments (cash) or indirect such as health insurance, funeral cost, reimbursement of wage loss, or travel cost for the family to the medical center to give consent. In Saudi Arabia, the government will reward 50,000 riyals to the deceased's family and 50\% discount of Saudi Airlines ${ }^{24)}$. In Qatar, travel and counseling support is provided for the deceased's family at the time of donation ${ }^{25}$. While in Singapore, the government provides $50 \%$ subsidy of the medical expense for the deceased's immediate family for 5 years following donation ${ }^{26)}$. Table 1 summarizes the advantages and drawbacks of each regulations.

\section{The impact of the implemented policy on cadaveric kidney donation}

It is quite difficult to withdraw which the best system to increase kidney donation rate since each regulation has its own benefits and drawbacks. To see the actual condition of the current kidney donation, Figure 1 shows cadaveric kidney donation rate in presumed consent 
Table 2. Statistical data of organ donation rate and public attitudes.

\begin{tabular}{lcccc}
\hline Country & Legal System & $\begin{array}{c}\text { Organ Donation } \\
\text { Number* per } \\
\text { year (PMP) }\end{array}$ & $\begin{array}{c}\text { Willingness to } \\
\text { donor (\%) }\end{array}$ & $\begin{array}{c}\text { Family's willingness to } \\
\text { consent organ } \\
\text { donationl }^{38)}\end{array}$ \\
\hline $\begin{array}{l}\text { Netherlands } \\
\text { Romania }\end{array}$ & Informed Consent & 56.1 & 64 & 62 \\
\hline Spain & Presumed Consent & 49.3 & 31 & 34 \\
Bulgaria & 5.31 & 61 & 59 \\
\hline
\end{tabular}

countries, informed consent countries and countries having financial compensation. Although the 7 highest donation rate are occupied by presumed consent countries, some countries with relatively high donation rate also practice informed consent system (Figure 1). The donation rate in the U.S, for example, is comparable with that in Belarus, though these countries practice different systems. Yet, it is also surprising to see that the lowest donation rate is occupied by Bulgaria which is a presumed consent country. Saudi Arabia is also suffering from low donation rate though having financial compensation scheme. These suggests that the implemented policy may have less effect on the number of kidney cadaveric donation and that other factors may take into account.

\section{Key factors to increase cadaveric kidney donation}

The implementation of organ donation policy should not be based upon success story on other countries. Every society differs from one another which is defined by culture, religious view, and life values. It is therefore important to examine the public attitudes toward organ donation. This includes the willingness to donate organ and willingness to give consent for family member to donate.

Table 2 shows statistical data of organ donation rate and public attitudes in some European countries. It obviously showed that countries with high level of donation rate (such as Netherlands and Spain) tend to have higher level of willingness to donor and willingness to give consent to other family member to donate (>50\%), regardless the system practiced in those countries. On the contrary, countries with low level of such public attitudes toward organ donation (such as Romania and Bulgaria) have low donation rates. Those suggest that there is a linier relation between public attitudes and organ donation rate.

According to the Eurobarometer survey in 2010, the low level of public attitudes is influenced by several reasons which are dominated by the lack of public trust in the organ donor and transplant system and the fear of manipulation of human body. Public distrust of the system leads to an increase number of the unwilling organ donor and a protest against presumed consent system in Russia ${ }^{27,28)}$. To promote and improve the public awareness on organ donation and transplantation, educational campaign is a vital approach. Studies showed that the more the public is informed about the various aspect of organ donation and transplant, the higher the public awareness ${ }^{29,30)}$.

Other important factors are the transplantation system and infrastructure. It is reported that a sharp increase in waiting-patient numbers for transplant is not caused by the fact that there is lack of voluntary donor, rather caused by procedural matters such as no immediate follow up from a medical professional to recover vital organ from a deceased donor ${ }^{31)}$. In other words, medical authority failed to identify every potential donor in their hospital. Lack of transplant coordinator was considered to be the main reason behind kidney shortage ${ }^{32,33)}$.

The kidney donation process, from the detection of potential donor until the kidney is successfully transplanted into recipient's body, should be performed effectively in relatively short time, less than 30 hours $^{34)}$, otherwise the kidney will lose its viability. Therefore, these complex and multiple-steps procedures require good communication and coordination between the donor hospital, family (for giving consent immediately), and transplant center. It is observed that countries with relatively high donation rate have mostly a well-established management system that supports the process, such as the US, Netherlands, Spain and Iran, as summarized in Table 3. The system in those countries consists of at least: Transplant center, Donor Hospital and National Transplant Network.

Transplant center is a hospital that has transplant facility and trained transplant team to perform organ transplantation. Transplant network is a competent authority to procure and allocate organs in a regional or national level. The transplant network can be a private or public organization under a license of the government like in the US, Spain and Netherlands or an association of organ transplant that is run voluntary like in Iran. The function of these bodies is mainly to link all professionals involved in organ donation and transplantation. Also in most of established system, there is a very clear and effective procedure on who and how to approach a family consent when a deceased donor is available. In Spain, a transplant coordinator (usually a 
Table 3. Components of Organ Donation Systems in High Kidney Donation Rate Countries. *kidney transplant center, **dialysis units.

\begin{tabular}{|c|c|c|c|}
\hline Countries & $\begin{array}{l}\text { Number of } \\
\text { Transplant Center }\end{array}$ & $\begin{array}{l}\text { Number of Donor } \\
\text { Hospitals }\end{array}$ & Transplant Network/Number \\
\hline $\begin{array}{l}\text { Netherlands }{ }^{39,4} \\
0\end{array}$ & 8 & 100 & $\begin{array}{l}\text { The Organ Center of the Dutch Transplant } \\
\text { Foundation (NTS)/ } 60 \text { units }\end{array}$ \\
\hline $\operatorname{Iran}^{41}$ & 25 & $302 * *$ & $\begin{array}{l}\text { Dialysis and Transplant Patients Association } \\
\text { (DATPA)/ } 79 \text { regionals units }\end{array}$ \\
\hline $\mathrm{US}^{42}$ & $244 *$ & 6-78/ OPO & $\begin{array}{l}\text { Organ Procurement Organization (OPO) / } 58 \\
\text { regional units }\end{array}$ \\
\hline Spain $^{43}$ & 29 & 170 & $\begin{array}{l}\text { The National Transplant Organization (NTS)/ } 17 \\
\text { regional units }\end{array}$ \\
\hline
\end{tabular}

physician) is in charge to identify every deceased potential donor and approaching their family to get consent $^{35)}$. In Netherlands, a special trained-donation practitioner is recruited to assist every transplantation process such as approaching the deceased's family to get a consent ${ }^{36)}$.

To establish such an integrated system, a high investment as well as government's commitment are needed. These costs include building the transplant facility and training the transplant personnel. Finally, the combination between good public attitudes and effective transplantation system may result a positive effect in the increasing number of kidney donation rate.

\section{Conclusion}

The effectiveness of kidney donation and transplantation policies have been discussed through a comparative study. It was found that the reviewed policies have a little correlation on the level of kidney donation rate. It seems that these policies were not effective without good public attitudes including willingness to donate their own organ or those of deceased family member. Furthermore, the transplantation system and facilities such as, transplant center hospitals, skilled medical personnel and transplant network also played important role to increase kidney donation. In conclusion, to increase the supply of kidney, the implemented policy should be supported by a good public attitude and an effective transplantation system.

\section{Acknowledgements}

The author would like to show gratitude to Advanced Graduate Program in Global Strategy for Green Asia under Kyushu University for the support.

\section{References}

1) Global Observatory on Donation and Transplantation. Organ Donation and Transplantation Activities 2015. (2017).

2) Stokes, J. B. Consequences of Frequent Hemodialysis: Comparison to Conventional Hemodialysis and Transplantation. Trans. Am. Clin.
Climatol. Assoc. 122, 124-136 (2011).

3) US Renal Data System. USRD 2009 Annual Data Report. (2009).

4) Rosselli, D., Rueda, J.-D. \& Diaz, C. Cost-effectiveness of kidney transplantation compared with chronic dialysis in end-stage renal disease. Saudi J. Kidney Dis. Transplant. 26, 733 (2015).

5) Haller, M., Gutjahr, G., Kramar, R., Harnoncourt, F. \& Oberbauer, R. Cost-effectiveness analysis of renal replacement therapy in Austria. Nephrol. Dial. Transplant. 26, 2988-2995 (2011).

6) United States Renal Data System. 2016 USRDS annual data report: Epidemiology of kidney disease in the United States. National Institutes of Health, National Institute of Diabetes and Digestive and Kidney Diseases (2016).

7) National Institutes of Health, National Institutes of Diabetes \& Digestive \& Kidney Disease, D. of K. U. \& H. D. USRDS 2011 Annual Data Report: Atlas of Chronic Kidney Disease and End-Stage Renal Disease in the United States. Natl. Institutes Heal. Natl. Inst. Diabetes Dig. Kidney Dis. 1-26 (2011).

8) Salvatori, M., Peloso, A., Katari, R. \& Orlando, G. Regeneration and bioengineering of the kidney: Current status and future challenges. Curr. Urol. Rep. 15, (2014).

9) Nakao, K. et al. The development of a bioengineered organ germ method. Nat. Methods 4, 227-30 (2007).

10) American Society of Nephrology (ASN). Closer to developing a bioartificial kidney. ScienceDaily (2016).

11) Suzanne Hodsden. World's first implantable artificial kidney could enter human trials by 2017. Med Device ONLINE (2016).

12) Caulfield, T., Nelson, E., Goldfeldt, B. \& Klarenbach, S. Incentives and organ donation: What's (really) legal in Canada? Canadian Journal of Kidney Health and Disease 1, 1-5 (2014).

13) Rithalia, A. et al. A systematic review of presumed consent systems for deceased organ donation. 
Health technology assessment (Winchester, England) 13, (2009).

14) Ugur, Z. B. Does presumed consent save lives? Evidence from Europe. Heal. Econ. (United Kingdom) 24, 1560-1572 (2015).

15) Rithalia, A., McDaid, C., Suekarran, S., Myers, L. \& Sowden, A. Impact of presumed consent for organ donation on donation rates: A systematic review. BMJ 338, 284-287 (2009).

16) Matas, A. J., Hippen, B. \& Satel, S. In defense of a regulated system of compensation for living donation. Curr. Opin. Organ Transplant. 13, (2008).

17) Fevrier, P. \& Gay, S. Informed Consent Versus Presumed Consent: The Role of the Family in Organ Donations. SSRN Electron. J. (2004). doi:10.2139/ssrn.572241

18) The Deceased Donation Process. Available at: https://organdonor.gov/about/process/deceased-don ation.html\#register. (Accessed: 16th February 2018)

19) Girlanda, R. Deceased organ donation for transplantation: Challenges and opportunities. World J. Transplant. 6, 451 (2016).

20) Ugur, Z. B. Does Presumed Consent Save Lives? Evidence from Europe. Health Econ. 24, 1560-1572 (2015).

21) Chong, J. L. Policy options for increasing the supply of transplantable kidneys in Singapore. Singapore Med. J. 57, 530-532 (2016).

22) Consent for Organ Donation. Available at: http://health.gov.ie/wp-content/uploads/2014/04/co nsentoptions.pdf. (Accessed: 26th February 2018)

23) Matas, A. J. Incentives for organ donation: Proposed standards for an internationally acceptable system. in American Journal of Transplantation 12, 306-312 (2012).

24) Jingwei, A. H., Yu-Hung, A. L. \& Ching, L. Living Organ transplantation Policy Transition in Asia: Towards Adapive Policy Changes. Glob. Heal. Gov. 3, (2010).

25) Alkuwari, H. et al. The Doha donation accord aligned with the declaration of Istanbul: Implementations to develop deceased organ donation and combat commercialism. Transplantation 97, 3-4 (2014).

26) John S. Gill. Incentives in Kidney Donation: A Global Perspective. Available at: https://www.myast.org/sites/default/files/ceot2016/ Gill_CEOT2016.pdf. (Accessed: 26th February 2018)

27) Burkov, A. Russia's unknown, unwilling organ donors. The Moscows Times (2014).

28) Bigg, C. Gutted Like a pig: Griefing mother takes on Russia's organ donation system. RadioFreeEurope (2016).

29) Terbonssen, T., Settmacher, U., Wurst, C., Dirsch, O. \& Dahmen, U. Effectiveness of Organ Donation Information Campaigns in Germany: A Facebook
Based Online Survey. Interact. J. Med. Res. 4, e16 (2015).

30) Scheuher, C. What is being done to increase organ donation? Crit. Care Nurs. Q. 39, 304-307 (2016).

31) Gen\&ccedil;; R. The Logistics Management and Coordination in Procurement Phase of Organ Transplantation. Tohoku J. Exp. Med. 216, 287-296 (2008).

32) DuBose, J. \& Salim, A. Aggressive organ donor management protocol. Journal of Intensive Care Medicine 23, 367-375 (2008).

33) Chaffin, J. S. \& Mischke, L. in (eds. Cooper, D. K. C., Miller, L. W. \& Patterson, G. A.) 11-17 (Springer Netherlands, 1996). doi:10.1007/978-0-585-34287-0_3

34) Collins, G. M., Hartley, L. C. J. \& Clunie, G. J. A. Kidney preservation for transportation experimental analysis of optimal perfusate composition. Br. J. Surg. 59, 187-189 (1972).

35) Girones-Guillem, P., Camano-Puig, R. \& Lillo-Crespo, M. [Transplant coordinator: organ donation process]. Cir Cir 82, 647-654 (2014).

36) Van Dalen, H. P. \& Henkens, K. Comparing the effects of defaults in organ donation systems. Soc. Sci. Med. 106, 137-142 (2014).

37) IRODaT. International Registry in Organ Donation and Transplantation. IRODaT 1-14 (2016). doi:10.1016/j.transproceed.2013.11.138

38) European Commicion. Organ donation and transplantation-Special Eurobarometer 333a. $J$. Tenn. Med. Assoc. 74, 507-509, 515 (2010).

39) Paul, K. T., Avezaat, C. J., Ijzermans, J. N., Friele, R. D. \& Bal, R. A. Organ donation as transition work: Policy discourse and clinical practice in The Netherlands. Heal. An Interdiscip. J. Soc. Study Heal. Illn. Med. 18, 369-387 (2014).

40) Jansen, N. E. et al. Appointing 'trained donation practitioners' results in a higher family consent rate in the Netherlands: A multicenter study. Transpl. Int. 24, 1189-1197 (2011).

41) Jahromi, A. H., Fry-Revere, S. \& Bastani, B. A revised Iranian model of organ donation as an answer to the current organ shortage crisis. Iran. J. Kidney Dis. 9, 354-360 (2015).

42) Shafer, T. J. et al. US organ donation breakthrough collaborative increases organ donation. Crit. Care Nurs. Q. 31, 190-210 (2008).

43) Manyalich, M., Cabrer, C., Vilardell, J. \& Miranda, B. Functions, responsibilities, dedication, payment, organization, and profile of the hospital transplant coordination in Spain in 2002. in Transplantation Proceedings 35, 1633-1635 (2003). 